ISSN: 2664-8148 (Online)
Liberal Arts and Social Sciences
International Journal (LASSIJ)
https://doi.org/10.47264/idea.lassij/3.1.6
Vol. 3, No. 1 (January-June) 2019,61-73
https://www.ideapublishers.org/lassij

\title{
Sino-African Relations: Economic Opportunities and Challenges for China
}

\author{
Sohail Ahmad ${ }^{1 *}$, Azka Gull $^{1}$ and Sehrish $\operatorname{Irfan}^{2}$ \\ 1. International Relations Program, Department of Humanities, COMSATS University, \\ Islamabad Pakistan. \\ 2. Department of Economics, Faculty of Business Administration, COMSATS University, \\ Islamabad Pakistan.
}

\begin{abstract}
Africa is known for its massive labour force and natural resources. In terms of economic growth, African countries have faced prolonged phases of economic crises. China is a significant contributor in Africa's economic stability. This paper analyses and evaluates the current opportunities and challenges related to China's engagements in Africa and its policies for triggering economic development in African countries. China's comprehensive approach is more concentrated on the sustainable development of the domestic infrastructure and job creation for the Africa communities. But there exists a gap in the current Chinese policies that have deepened the concerns of the locals about economic growth and progress. China needs to develop policies that would be mutually beneficial, these policies must ensure economic stability, job creation and growth. Various ongoing development projects initiated by the Chinese have in fact created insecurities amongst the Africans. This anxiety among the locals have become a major hurdle for China's plans in the continent. Ongoing Chinese policies need to be innovative along with the integration of modern economic models. A reform in the current policies would ensure maximum benefits for both economic partners.
\end{abstract}

Keywords: Sino-Africa Relations, Economic Opportunities, Trade Relations, FDIs

\section{Introduction}

The Chinese economic relations with African countries have multiplied in the past years. However, along with enhanced opportunities for cooperation and economic growth, the relationship is faced with major hurdles as well. The relationship between China and the less developed countries of Africa is not merely limited to the economic and political spheres, overtime, the scientific and cultural dimensions were incorporated as well. The robust relation between China and the African countries is multidimensional and often looked upon suspicion by the Western world. This research aims to assess the opportunities and challenges faced by the Chinese economic initiatives including trade, loans, foreign direct investment, etc., in Africa. China has divided its relationship with Africa countries into two main categories i.e. cooperative partnership and strategic partnership. This relationship between China and Africa holds precarious importance for the development of African countries. Thus, it has a significant influence on the geostrategic aspects (Pelssis, 2014). 


\section{Literature Review}

The Sino-African relationship started in 1956, at the time when China established diplomatic ties with Egypt along with Algeria, Ghana, and Guinea. Sino-African ties strengthened after the creation of the Forum on China and Africa Cooperation (FOCAC) in 2000 (Novati \& Montanini, 2016; Thompson, 2012). Sino-Africa relationship passed through three stages. The first stage included decolonising based on the mutual support of political powers under the Bandung Conference sponsored by the non-aligned nations in 1955 . The second stage, which started from the 1990s and onward contained the resources essential for the industrialisation. The third phase consisted transfer of small and medium enterprises to the African countries (Elsenman, Mitchell, \& Heginbotham, 2015; Kaplinsky \& Morris, 2010). In Africa, China encounters a mix of opportunities and challenges, which it addresses differently for various sectors (i.e., extractive and manufacturing industries) and stakeholders (such as elites, leaders, citizen, consumer and producers etc.). In this regard, China has a strong affinity towards changing or undermining the international regulation and codes of practice on concerning issues, for instance, the environment or arms sales, which may have profound implications for the region (Goldstein, Pinaud, \& Reisen 2006). According to observers some African countries are devising policies to significantly maximise their gains and interests in regard to China (Alden, 2005). The multi-layered interaction has effectively deepened the relationship between the two economic partners (Shelton, 208). It appears that China has gained more attention among the African public owing to its policies related to environment and employment and manufacturing of cheap products.

Over time Beijing's influence on Africa has accumulated. It holds a dominant position to resolve bottlenecks in the infrastructure sector. It retains a favourable position to create linkages to China's export market and ensure the security of labourers, raw material along with increased internationalisation of the Chinese businesses and firms. In addition, the Chinese industry is gaining access to the regional African markets along with connections to other sub regions for selling Chinese manufactured products (Elsenman et al., 2015). The Chinese government is financing the African infrastructure sector by launching more than 3000 projects. From the year 2000-2014, China extended a loan grant of US\$ 86 billion to Africa (Witney \& Wiegert, 2018). China's financing policies are moderate towards repayment, as it is focused more on the commercial aspects. China is now abandoning the traditional model of "resources for infrastructure" for a new model i.e. equity investment (Sun, 2019). According to China Africa Research Initiative, Angola is receiving 34\%, Kenya 22\%, Ethiopia 2\%, South Africa 20\%, Sudan 16\%, and Zambia 19\% of the Foreign Direct Investment (FDI) from China. Whereas Jayaram, Kassiri \& Sun (2017) reported that China's FDI in Africa is continuously increasing the jobs, transfer of modern technology, skills development and the practices that are related to the Western business norms. Although a separate issue, yet, there may be negative ramifications for the countries actively seeking Chinese loans. It is believed that China's multibillion project i.e., Belt and Road Initiative (BRI) may increase the debt on developing countries (Rehman, Hakim, Kha, \& Khan, 2018). China is considered a largest creditor of the Sub Africa. China's enhanced integration and investment could affect domestic market and encourage cheap labour. Western scholars show concern that Africa's over reliance on China may undermine the sovereignty of these African countries (Khatoon, Rahim, \& Ali, 2018).

\section{Methods and Materials}

This study employs mixed method research, where both the qualitative and quantitative data 
is used. This work is descriptive analytical in nature, analysing the opportunities and challenges faced by the Chinese investment in Africa. The opportunities for the Sino African economic ties are described in detail supported by quantitative data. An in-depth analysis of the challenges that have surfaced over the years for the Chinese investment has been made. Secondary sources such as books, online data bases, research articles and various annual reports have been consulted in compiling the quantitative as well as qualitative data. The research article is divided into four sections. The first section consists of introduction and second section presents a brief literature review of the study. The research methodology including the methods and materials used for this research are discussed in the third section. The analysis and discussion are presented in the fourth section. The last section concludes the key findings of the research.

\section{Analysis and Discussion}

This section has been divided into two main sub-sections. The first one focuses on the economic opportunities and the second one focuses on the major challenges to Chinees economic initiatives and support in the African continent.

\subsection{Economic Opportunities related to Africa and China Relationship}

This section will explain the numerous opportunities for Sino-African engagement. These are subdivided into trade, FDI, loans and financial packages, strengthening cooperation in agriculture and food security.

\subsubsection{Trade-Related Opportunity}

Even though the recovery of the African economy is sluggish, the trade development between the countries is perpetually increasing. In the year 2009, China was considered as Africa's number one trading partner. Chinese export to Africa increased over the years, in 2017 alone it was US\$ 58.55 billion, as shown in Figure-1. The total trade between China and Africa was highest in 2014, and the lowest in the year 2009, i.e. US\$ 89.35 billion.

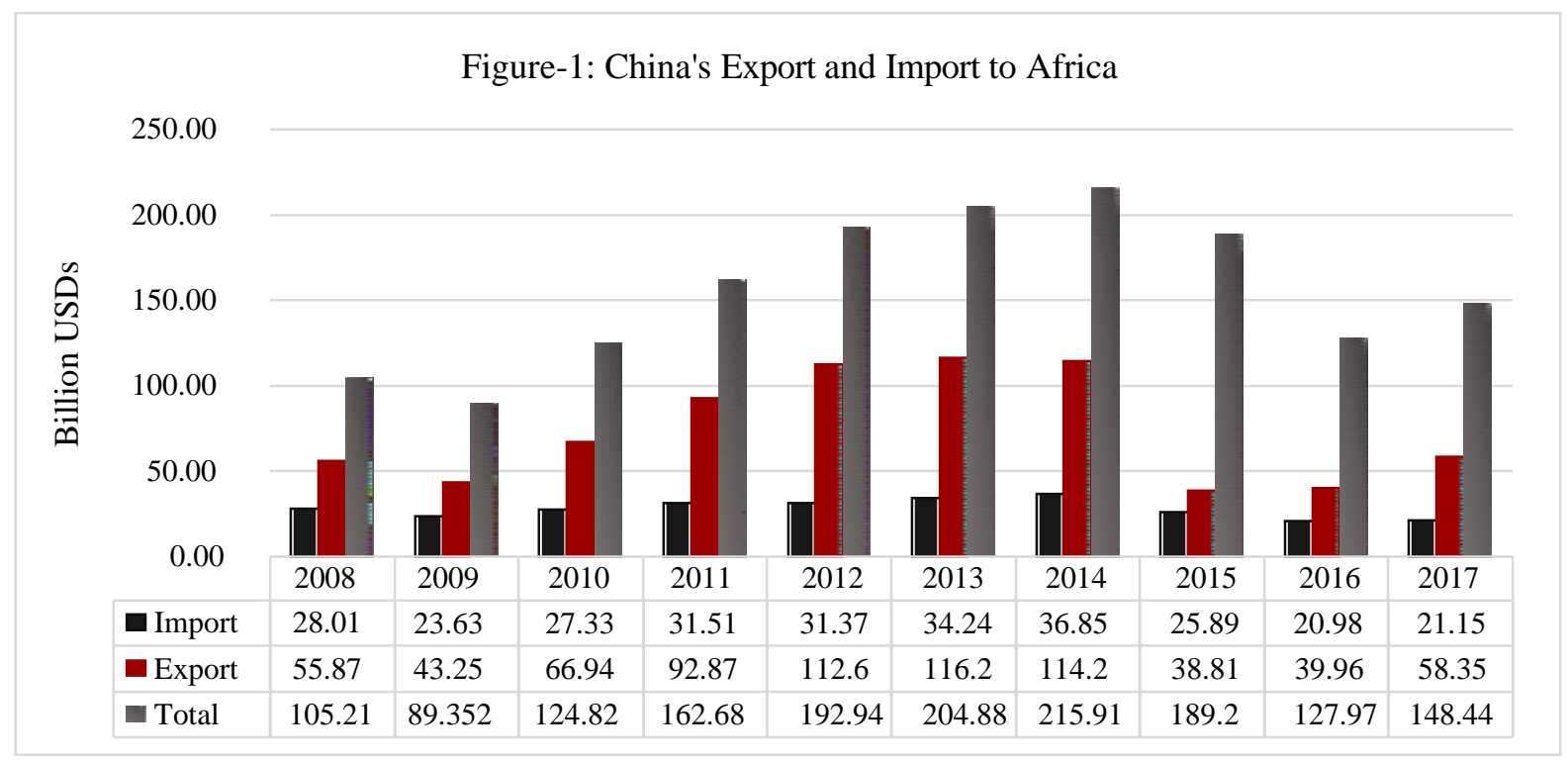

Source: China-Africa Research Initiative, John Hopkins School of Advanced International Studies 
To analyse China's impact in the terms of trade in Sub-Saharan Africa, quantitative analysis was conducted for the years 2010-2017. Data on imports and exports are collected from the China-Africa Research Initiative. The purpose was to calculate the Chinese contribution in the growth of African economies from 2010 to 2017. The primary purpose of analysis was to measure the terms of trade of every country. The terms of trade can be defined as the ratio of the export index to the imports (see Table-1). Then based on the terms of trade, countries are either classified as winners or losers. Out of 51 countries, $60 \%$ are winner, and $40 \%$ are losers in case of the percentage change in the terms of trade.

Table-1: African Terms of Trade and Percentage Change (2010-2017)

\begin{tabular}{|c|c|c|c|c|c|c|c|c|c|}
\hline \multirow{2}{*}{$\begin{array}{l}\text { Name of } \\
\text { Countries }\end{array}$} & \multicolumn{8}{|c|}{ Terms of Trade Index } & \multirow{2}{*}{$\begin{array}{l}\text { \% Change } \\
2010-2017\end{array}$} \\
\hline & 2010 & 2011 & 2012 & 2013 & 2014 & 2015 & 2016 & 2017 & \\
\hline Algeria & 76.9 & 51.6 & 43.8 & 63.0 & 127.3 & 223.6 & 521.5 & 342.5 & 44.0 \\
\hline Angola & 54.0 & 68.7 & 74.0 & 76.3 & 118.2 & 142.9 & 74.0 & 67.1 & 24.2 \\
\hline Benin & 86.9 & 78.2 & 44.3 & 69.8 & 62.8 & 184.4 & 176.8 & 101.0 & 16.2 \\
\hline Botswana & 273.3 & 241.6 & 60.2 & 30.2 & 32.4 & 64.0 & 133.1 & 273.8 & 0.2 \\
\hline Burundi & 27.5 & 8.8 & 12.4 & 15.6 & 35.5 & 40.6 & 46.9 & 18.6 & -32.3 \\
\hline Central Africa & 171.8 & 192.1 & 332.0 & 277.6 & 199.9 & 181.2 & 215.5 & 191.9 & 11.7 \\
\hline Chad & 758.5 & 405.9 & 337.7 & 158.3 & 165.7 & 138.7 & 175.8 & 428.2 & -43.5 \\
\hline Congo & 53.7 & 49.7 & 54.2 & 64.7 & 85.2 & 187.2 & 150.6 & 59.6 & 10.9 \\
\hline Dem. Rep & 66.8 & 92.5 & 84.0 & 122.3 & 171.1 & 189.7 & 168.4 & 104.3 & 56.1 \\
\hline Egypt & 97.0 & 70.7 & 91.7 & 66.5 & 132.9 & 767.9 & 278.0 & 104.2 & 7.4 \\
\hline Equ. Guinea & 224.3 & 46.9 & 58.4 & 42.6 & 32.3 & 263.8 & 69.1 & 33.0 & -85.3 \\
\hline Eritrea & 39.4 & 182.0 & 45.5 & 2.9 & 0.3 & 3.2 & 0.4 & 0.3 & -99.3 \\
\hline Ethiopia & 75.7 & 52.0 & 84.8 & 101.5 & 102.3 & 620.5 & 131.4 & 127.8 & 68.8 \\
\hline Gabon & 97.9 & 215.5 & 319.1 & 222.2 & 123.5 & 279.1 & 120.9 & 89.8 & -8.3 \\
\hline Guinea & 17.0 & 89.8 & 152.0 & 23.9 & 59.1 & 109.2 & 4.0 & 1.9 & -89.0 \\
\hline Kenya & 105.8 & 92.1 & 123.6 & 141.5 & 148.6 & 139.1 & 133.6 & 70.1 & -33.8 \\
\hline Lesotho & 43.8 & 32.9 & 58.2 & 22.4 & 24.5 & 23.1 & 9.3 & 8.2 & -81.2 \\
\hline Liberia & 41.2 & 25.3 & 3.2 & 3.0 & 1.2 & 1.7 & 7.0 & 15.3 & -62.7 \\
\hline Libya & 72.3 & 55.3 & 59.3 & 220.3 & 470.7 & 315.1 & 543.1 & 119.5 & 65.3 \\
\hline Madagascar & 52.2 & 67.5 & 65.7 & 51.3 & 88.4 & 70.1 & 81.3 & 61.5 & 17.8 \\
\hline Mali & 72.1 & 44.0 & 19.3 & 39.8 & 68.7 & 64.3 & 82.1 & 109.8 & 52.3 \\
\hline Mauritius & 80.3 & 105.8 & 119.4 & 104.0 & 109.4 & 113.1 & 79.4 & 70.1 & -12.8 \\
\hline Morocco & 96.7 & 112.7 & 98.8 & 108.4 & 100.8 & 97.8 & 98.0 & 86.0 & -11.1 \\
\hline Mozambique & 129.2 & 142.5 & 122.1 & 138.0 & 62.5 & 224.2 & 142.9 & 129.4 & 0.1 \\
\hline Namibia & 56.3 & 148.5 & 214.9 & 220.9 & 203.1 & 273.4 & 191.3 & 108.0 & 91.9 \\
\hline Senegal & 102.4 & 104.1 & 162.5 & 263.9 & 369.1 & 206.2 & 142.8 & 143.3 & 40.0 \\
\hline Seychelles & 269.8 & 22.3 & 25.9 & 19.7 & 47.5 & 118.5 & 152.1 & 6.8 & -97.5 \\
\hline Sierra Leone & 176.1 & 154.8 & 9.6 & 2.0 & 1.9 & 32.4 & 19.5 & 13.8 & -92.1 \\
\hline Somalia & 34.8 & 12.9 & 26.6 & 6.7 & 5.6 & 9.9 & 29.2 & 32.8 & -5.7 \\
\hline Swaziland & 968.3 & 7469.6 & 24.1 & 18.0 & 48.1 & 8843.6 & 10812.9 & 660.4 & -31.8 \\
\hline Togo & 69.7 & 77.0 & 128.4 & 66.7 & 48.2 & 32.7 & 58.7 & 83.0 & 19.1 \\
\hline Tunisia & 120.4 & 76.7 & 118.9 & 108.1 & 88.8 & 101.8 & 141.1 & 101.3 & -15.9 \\
\hline Zambia & 97.9 & 186.1 & 217.2 & 200.4 & 197.8 & 258.7 & 187.8 & 190.2 & 94.2 \\
\hline Zimbabwe & 115.7 & 79.7 & 66.4 & 54.2 & 43.5 & 64.3 & 48.0 & 45.9 & -60.4 \\
\hline
\end{tabular}


All the products exported from China are of excellent quality and capable of meeting the demands of the African consumer market (The State Council China, 2013). The trade between Africa and China is expanding and improving with the passage of time. Africa's consumption capacity is rising. In 2012, the export of electrical products increased by $45.9 \%$. However, over the past decades, China's volume of import from Africa is increasing and the bulk quantity of commodities is also elevating such as agricultural products and crude oil. China is supporting economic growth in Africa by employing low tariffs for African products. The "Special Plan on Trade with Africa" is introduced and under this plan, the tariff rates were decreased to zero per cent. China is further facilitating the African countries about trade by improving its commodity and custom inspection facilities.

\subsubsection{Opportunities for FDI}

Most of the African countries have opened their markets to gain the attention of foreign investors. Whereas China took advantage of liberalisation policy and made massive investments. Africa is a resource haven, it contains vast reserves of energy, and China aims to access those reserves by establishing itself as a significant stakeholder in the African economy. Most of the banks that are established have supported China's relations with Africa. For instance, Chinese Export-Import Bank (Exim Bank) was established in 1994 to support Chinese FDI and export to Africa. Similarly, the Chinese Development Bank (CDB) was established to facilitate Chinese firms by providing loans for development in Africa (Tanimoune \& Renard, 2011). As shown in Figure-2, China's FDI in Africa increased over the years. But FDI from Unites State declined, in 2016, it turned to negative. Because African Bilateral Investment Treaty (ABIT) has been one of the low-cost policy tools for the investment. Its regional coverage rate has been $16 \%$, which is far lowest from Germany i.e., $96 \%$. Moreover, the US firms were not getting any protection from discriminatory treatment, expropriation, and weak legal system which Chinees firms received. This explains the improvement in FDI from China, while a gradual decline from the USA (Muzaffar, Yaseen, \& Rahim, 2017).

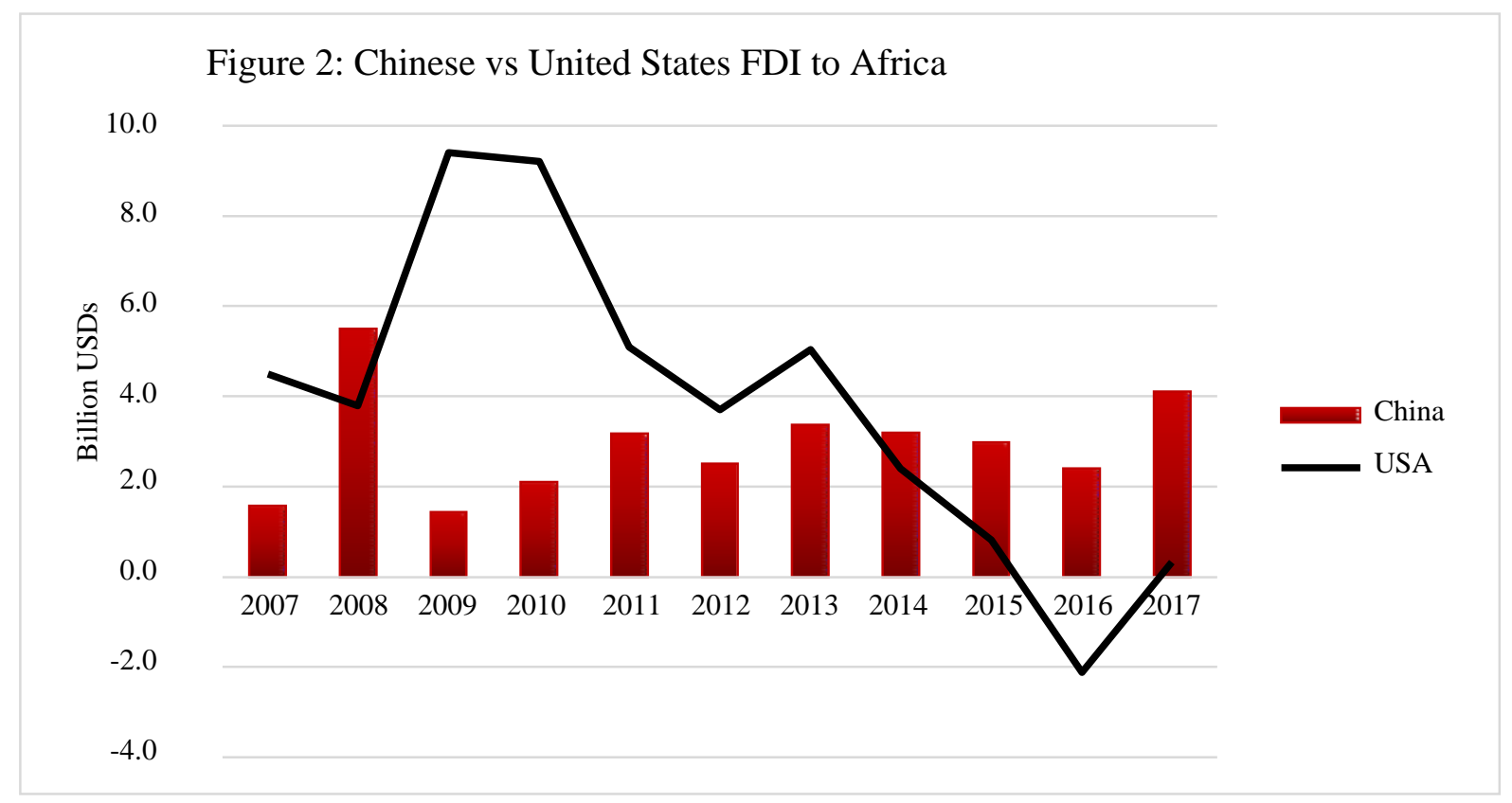

Source: China-Africa Research Initiative 
As shown in Figure-3, Chinese investment increased in the top five sectors of Africa i.e., construction, mining, manufacturing, financial package (assistance) and others. China's domestic growth skyrocketed in the last decade, the demands for new employees along with a desire to access natural resources compelled China to look for the market outside of the Asia. African countries allowed China to utilise its resources. African countries are rich in natural resources but have limited infrastructure to actually employ these resources to their advantage (Witney \& Wiegert, 2018). Up till now, China has invested in 3000 infrastructure projects in Africa. According to the China and Africa Research Initiative in 2017, China invested more than US\$ 4 billion in Africa. However, throughout the region, China invested more in the construction, transport and energy sector as shown in Figure-3.

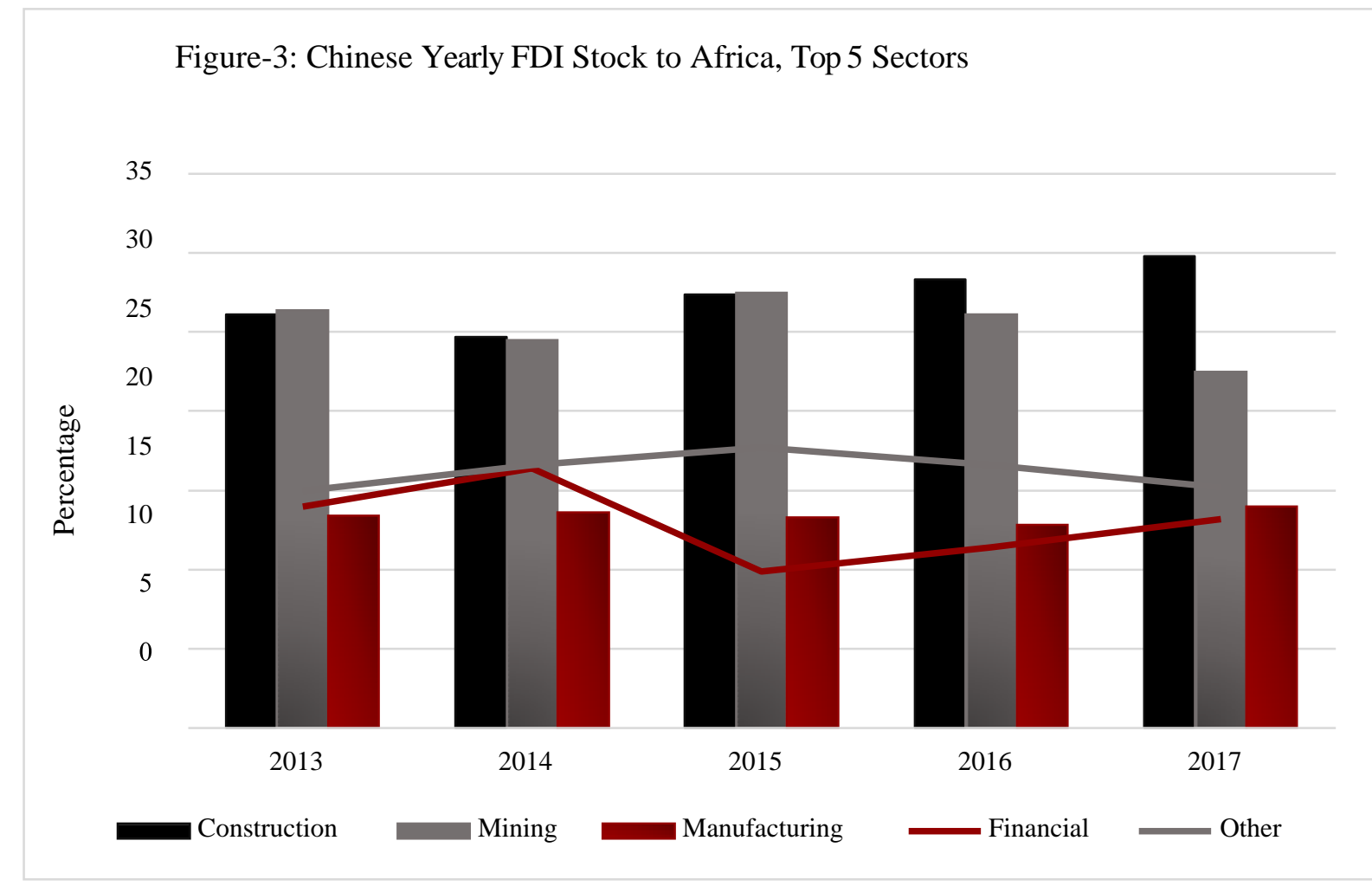

Source: China-Africa Research Initiative

The Chinese government has invested in Nigeria, to build railways. Likewise, China also has invested in Kenya, Zambia, Ethiopia, and many more to construct railways. It is reported that Export-Import Bank (Exim Bank) has invested 85\% which is approximately US\$ 475 million in the Light Rail of Addis Ababa and serves 4 million inhabitants of the city (Sow, 2018). Albeit China's rendezvous in Africa increases its economic benefits for example availability of low-price vehicle because of Chinese FDI in Kenya, Ethiopia, Nigeria, Mauritius, and South Africa. As shown in Figure-4, Chinese invested 24\% in Kenya, 11\% in Ethiopia and 38\% in Angola. China also invested in motor vehicles (South Africa, Ghana, Kenya) apparels, textile (Gambia, Nigeria, Mauritius) and in the cultivation of rice (Kenya, South Africa) (Ademola, Bankole, \& Adewuy, 2016). Hence, it is estimated that because of a1\% increase in FDI from China, the African GDP growth increases significantly to $0.607 \%$ (Doku, Akuma, \& OwusuAfriyie, 2017). 
Figure-4: Chinees Foreign Direct Investment across the Africa in 2017
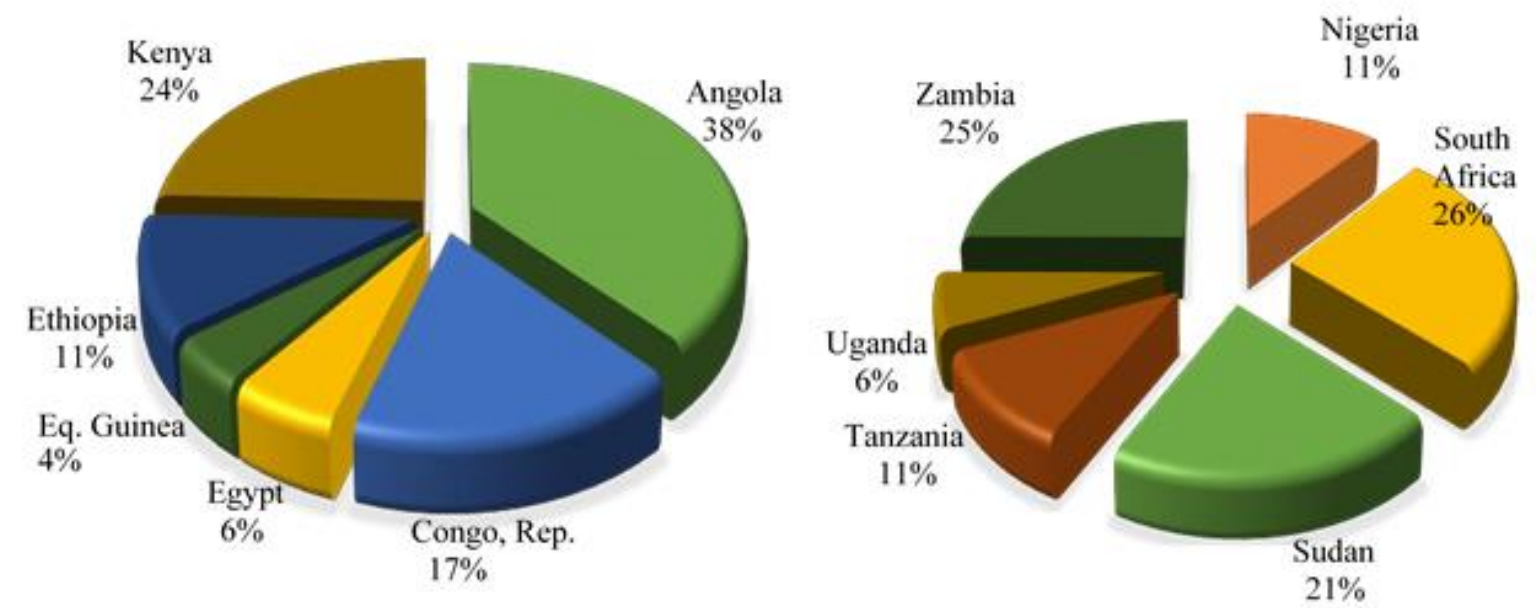

\subsubsection{Loans and Financial Packages from the Chinese Government}

China is altering its architecture of Global Aid, specifically for Africa by using flexible and generous packages (Naidu, 2008). However, grants and concessional loans for the purpose of resource security and construction in infrastructure is the primary framework followed by the Chinese government (Asongu \& Ssozi, 2015). Chinese Aid has helped Africa in accelerating its development process (Zafar, 2007). Chinese loans manifested to be an attractive and favoured modality for the support of the African continent (Giovannetti \& Sanfilippo, 2011). In Figure-5, it is depicted that the Chinese loans to Africa increased over the years but suddenly decreased after 2015. The Chinese government's pledge varies from US\$ 5 to 20 billion between 2006 to 2012 because of various causes like trade war, increase in capital outflows from the country and continuous progress of bad debt in China. The concessional loan decreased from US\$ 40 to 35 billion. Reason behind this strategy is Chinese apprehension for the return and commercial viability of financing from the government (Sun, 2018).

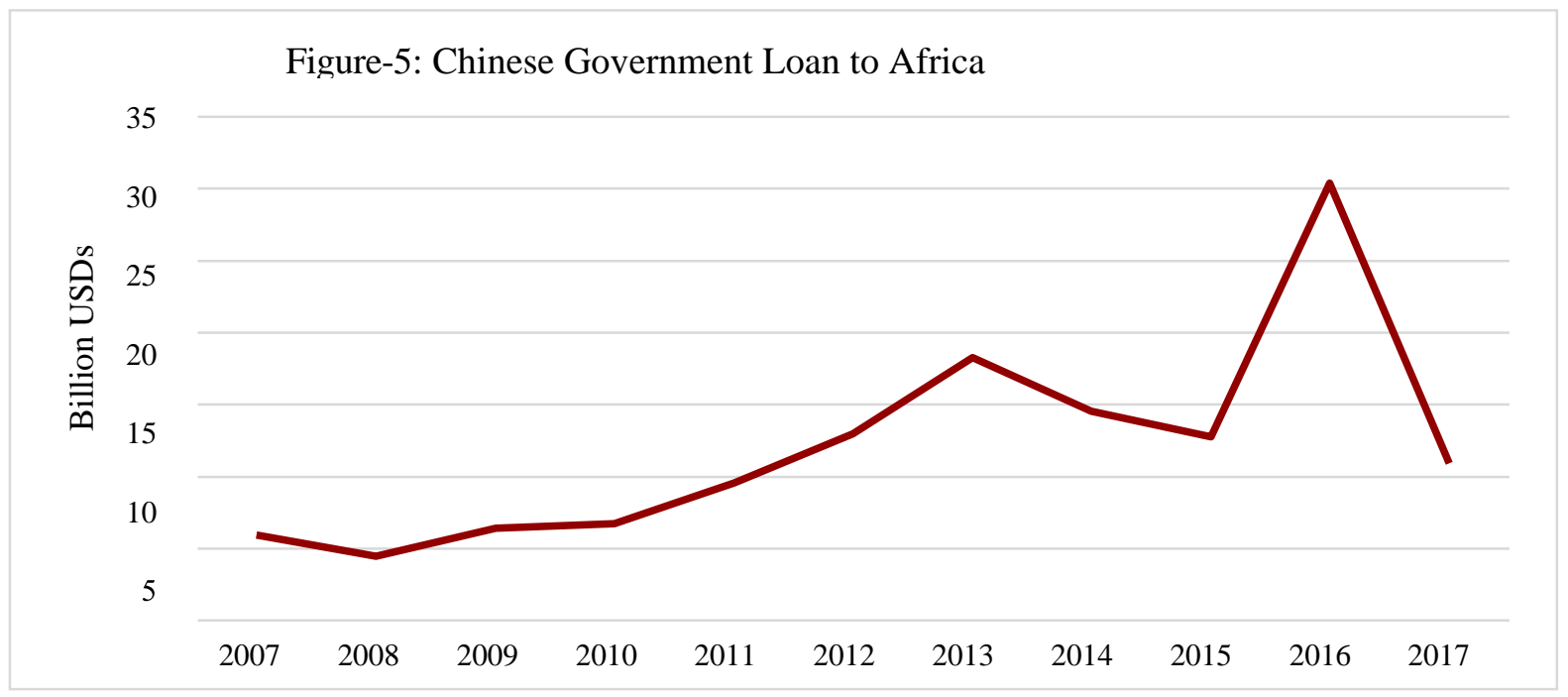

Source: China-Africa Research Initiative 
The Chinese lending to Africa increased since 2010. From 2010 to 2017, China has lent US\$ 143 million in which the transport and construction sectors remained the major focus of the Chinese government as shown in Figure-6. China showed the least concern to sectors of health, trade, banking, budget, and debt.

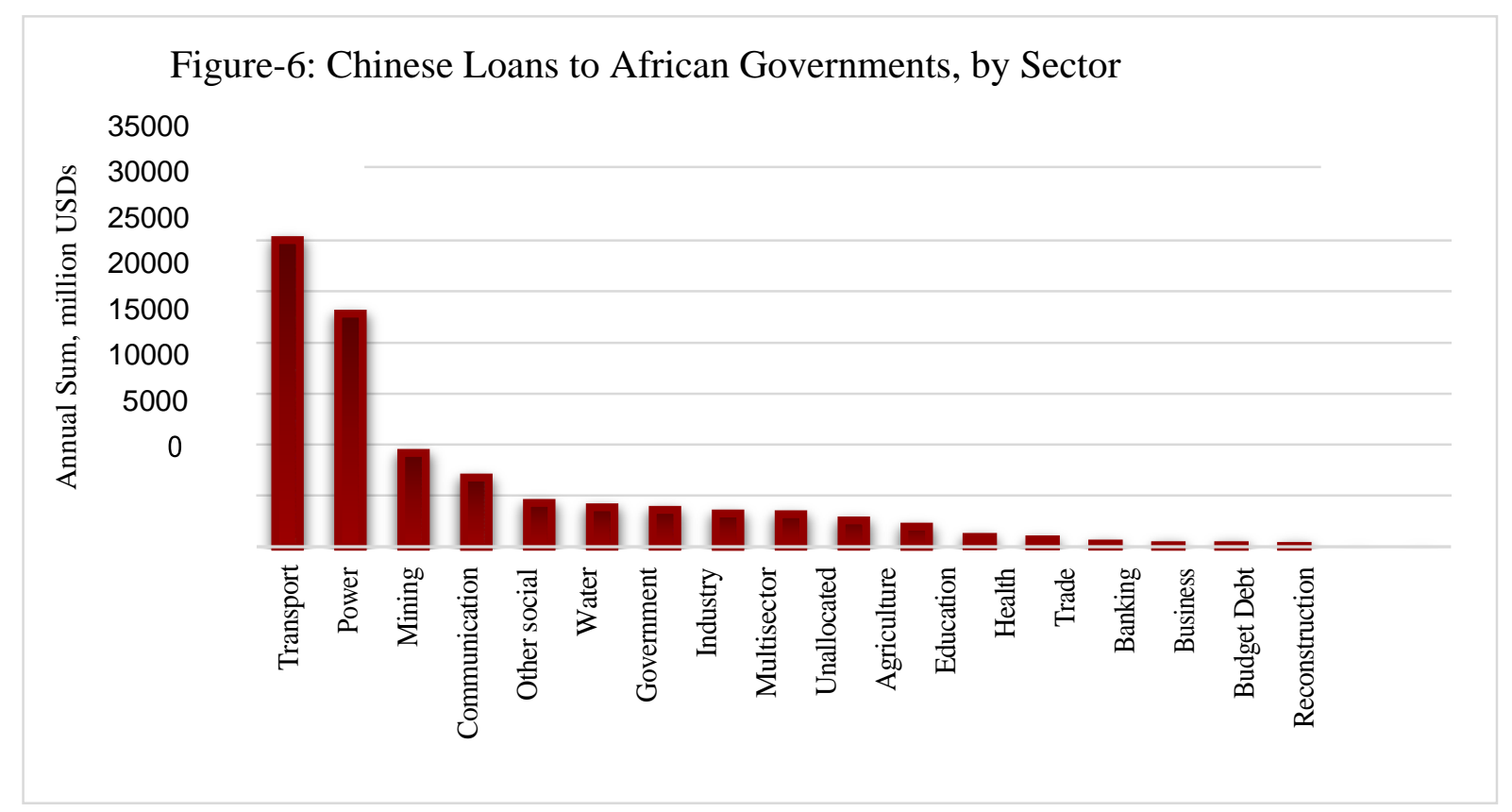

Source: China-Africa Research Initiative

\subsubsection{Strengthening Cooperation in Agriculture and Food Security}

The agriculture sector is considered as one of the main pillars in economic growth of a developing country. In Africa, China predicted favourable conditions and a bright prospect for agriculture cooperation. The Chinese government is putting a lot of effort to turn Africa's agriculture sector to a resource advantage area. The Sino-African agriculture trade has increased from the US\$ 1.58 to 2.49 billion, which cumulated an increase of $57.6 \%$. The most imported products are non-food items i.e., hemp, silk, etc. The primary reason is being the bulk of imports of African goods being covered under the zero tariff policies. The wellrenowned benefit of this policy is the impact on the export of sesame. Its export is increasing by $27 \%$ annually (Laingyu, 2018). It is predicted that export of sesame seed will exceed to 350,000 tons in 2019 (Huaxia, 2018). The China is not only exporting but also provides a grant to improve the breeding of seeds, cash crops, processing the agriculture products, and planting grains. In Malawi and Zambia, a Chinese enterprise worked to improve cotton processing and planting. This enterprise also works to improve the water conservancy, local farmland, and provide a suitable condition for the production of agriculture.

\subsection{Challenges Related to Africa and China Economic Relationship}

This section explains various challenges of Sino-Africa engagement. These are subdivided into labour and transfer of technology, governance and sovereignty issues, diversion of investment resources, structural changes, and less diversification and debt trap. 


\subsubsection{Labour and Transfer of Technology}

The employment generation for labour is one of the aims of Chinese engagement in Africa's manufacturing sector (Dollar, 2016). Whereas technology transfer from each investment of China is essential for the African countries to learn and develop the capability to generate their own framework. However, it is found that Chinese interference increased the displacement of local workers because the export of utensil and textile material is increased. As a result, Africa's local industries shut down on a large scale. On the contrary, China has mostly appointed Chinese workers in their projects, which has lowered the working opportunities for the African labours as illustrated in Figure-7. In addition, the standard working condition is not fulfilled by the Chinese investors and wages are below the standard (Besada, 2013). However, the investment of Chinese government is associated with the extraction of natural resources and decreasing the employment generation for the local people (Zafar, 2007). It has been observed that China is not emphasising the transfer of knowledge and there is quite a little transfer of technology to the projects related to infrastructure (Asongu, 2016).

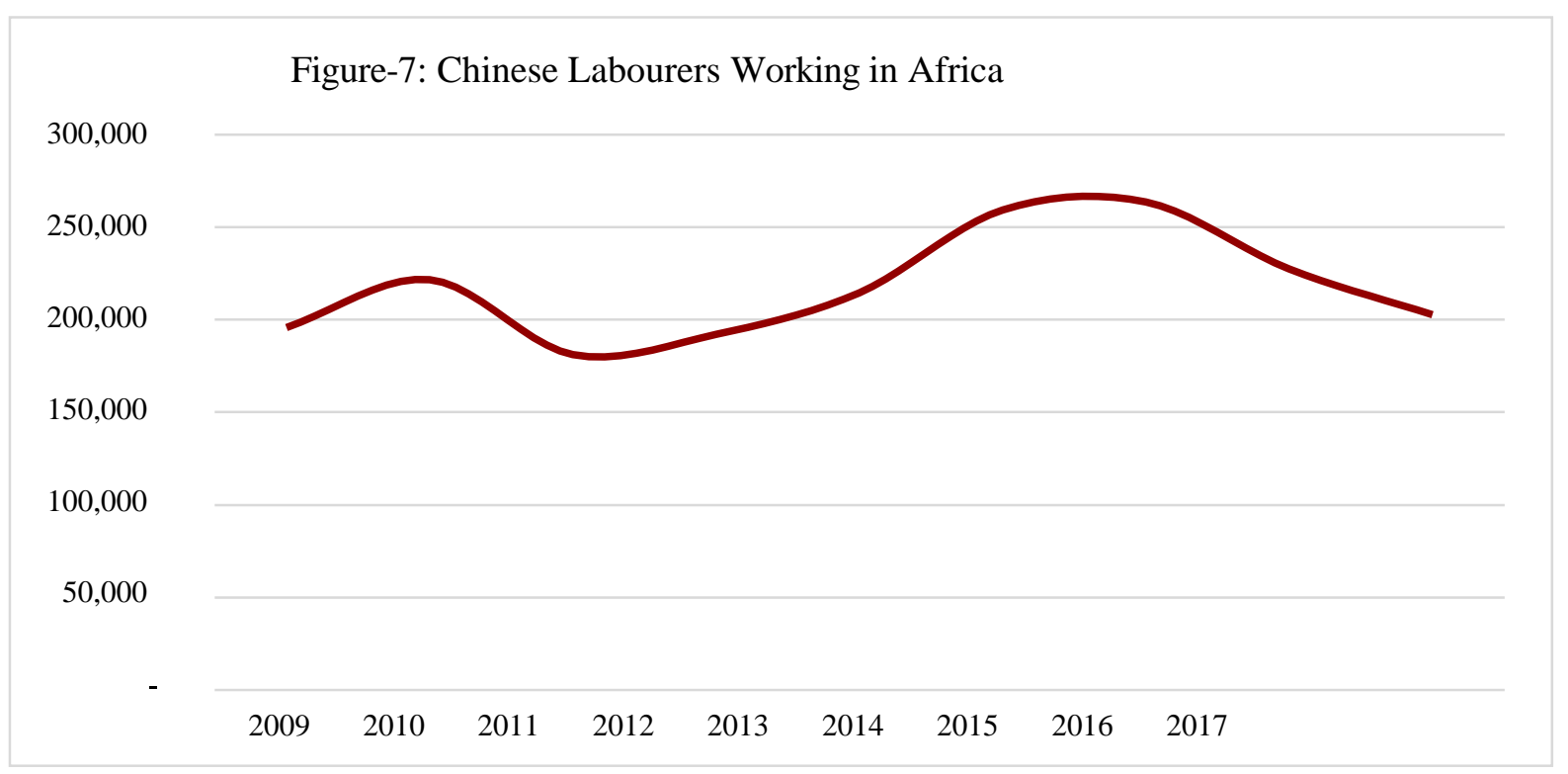

Source: China-Africa Research Initiative

\subsubsection{Governance and Sovereignty Issues}

Good governance and transparency are one of the essential components of long-term and sustainable development (Hellendroff, 2011). Many of the researchers focused on this component as a threat to African countries (Hill, 2015). Nonetheless, Beijing's constant interference is considered as a risk for the democracy, sustained development, and the effort for the human wellbeing (Hanusch 2012; Thompson, 2012). China's New Model is considered as a contradicted framework with respect to developing conventional strong institutions for sustained growth (Asongu \& Ssozi, 2015). The perpetual following of poor governance and investment in those countries would decrease growth (Chen, Dollar, \& Tang, 2016). However, the high level of corruption made the scenario even worst (Zafar, 2007).

\subsubsection{Diversion of Investment Resources}

It is examined that resource-rich nations in most of the cases suffered from Dutch disease 
because of the export dependence on natural resources (Adem, 2014). China is transferring its low valued manufacturing industries to the continent of Africa and assembling the raw material, this would decrease the benefits of the industrialisation prospects (Asongu \& Ssozi, 2015). It is believed that selfish policies of Chinese government are affecting the African efforts for good governance, industrialisation, and development (Sun, 2014).

\subsubsection{Structural Change and Less Diversification}

The only way through which the African less developed countries can transform itself form into a modern economy is more industrialisation for production and export of goods that the developed countries export. Chinese engagement in the African continent has not only switched its place globally in the division of labour but also obstruct the economic diversification, and this would push Africa towards de-industrialisation (Zafar, 2007).

\subsubsection{Debt Trap}

It is estimated that $40 \%$ of the African countries are digging deep into the debt crisis. The analysts illustrated that Chinese infrastructure projects are too much expensive and increasing the burden for the African government. The International Monetary Funds (IMF) has estimated the new debt crises brewing in the continent. About $20 \%$ of the African loans is from the Chinese government. This gives China a prominent position as a single creditor in case of Africa, which is estimated to about US\$ 132 billion from 2006 to 2017. In addition, 35\% of loans are from the multilateral organisations and $32 \%$ from the private lenders. It was estimated in 2015, by China Africa Research Initiative (CARI) that 17 African countries are at the highest point of debt risk as these are unable to pay the debt. In 2017, Zambia's total debt amount reached US\$ 8.7 billion, which was being lent by China. Whereas, 77\% of Djibouti's loan was owed by a Chinese lender (BBC News, 2018). This shows that African countries are engraving in deep debt crises with the passage of time.

\section{Conclusion}

The relationship between Africa and China in the sector of trade, aid, FDI and other sectors can be improved with the change of some economic policies. The proper utilisation of resources can lead to a win-win situation for both sides. China's focus is concentrated on the construction, infrastructure and manufacturing sector, and these sectors hold the dominant position when it comes to investment. However, the sector-specific engagement of China proved to be complementary for the assistance from other countries and helps to improve good governance. African governments are facing issues of finance for capital projects which are essential for development. China is using less bureaucratic prospects for implementing beneficial projects to reduce bottlenecks and hurdles in the manufacturing and infrastructure sectors. The long-term engagement of Chinese government could have negative ramifications on the environment, governance, and sovereignty of African countries. Moreover, the diversion of infrastructure also decreases growth. China must develop and implement policies which would enhance the employment generation, structural changes, and economic diversification for the win-win situation. 


\section{References}

Adem, S. (2014). Decoding the discourse on China in Africa. Journal of African Foreign Affairs, 1(2), 93-106. https://hdl.handle.net/10520/EJC167571

Ademola, O. T., Bankole, A. S., \& Adewuy, A. O. (2016). China-Africa trade relations: insights from AERC scoping studies. In The Power of Chinees Dragon (pp. 69-97). London: Palgrave Macmillan.

Alden, C. (2005). Leveraging the Dragon: Toward "an Africa that can say no". eAfrica, 3. South African Institute of International Affiars.

Asongu, S. A. (2016). Sino-African relations: A review and reconciliation of the dominant schools of thought. Politics and Policy, 44(2), 351-383. https://doi.org/10.1111/polp.12152

Asongu, S., \& Ssozi, J. (2015). Sino-African relations: Some solutions and strategies to the policy syndromes. Journal of African Business, 17(1), 33-51. https://doi.org/10.1080/15228916.2015.1089614

BBC News. (2018). Reality Check: Is China burdening Africa with debt? Retrieved from https://www.bbc.com/news/world-africa-45916060

Besada, H. G. (2013). Assessing China's relations with Africa. Africa Development, 38(1\&2), 81-106.

Chen, W., Dollar, D., \& Tang, H. (2016). Why is China investing in Africa? Evidence from the firm level. The World Bank Economic Review, 32(3), 610-632. https://www.brookings.edu/wp-content/uploads/2016/06/Why-is-China-investingin-Africa.pdf

Doku, I., Akuma, J., \& Owusu-Afriyie, J. (2017). Effects of Chinese foreighn direct investment on economic growth in Africa. Journal of Chinees Economic and Foreign Trade Studies. Retrieved from Insight: https://www.emerald.com/insight/content/doi/10.1108/JCEFTS-06-2017$\underline{0014 / \mathrm{full} / \mathrm{html}}$

Dollar, D. (2016). China's engagement with Africa: From natural resources to human resources. In: John L. Thornton: China Centre Monograph Series (7). China Centre at Brooking. https://www.brookings.edu/wp-content/uploads/2016/07/chinasengagement-with-africa-david-dollar-july-2016.pdf

Elsenman, J., Heginbotham, E., Mitchell, D. (ed.) (2015). China and the developing world: Beijing's strategy for the twenty-first century. New York: Taylor \& Francis. https://doi.org/10.4324/9781315642413

Giovannetti, G., \& Sanfilippo, M. (2011). China's economic cooperation with Africa. Journal of African Development 13(1\&2), 143-176. https://www.econstor.eu/bitstream/10419/183560/1/wp-206.pdf

Goldstein, A., Pinaud, N., \& Reisen, H. (2006, May 1). The rise of India and China: What's in it for Africa. Retrived from OECD iLibrary: https://www.oecdilibrary.org/content/paper/246616177271?crawler=true

Hanusch, M. (2010). African perspectives on China-Africa: Modelling popular perceptions and their economic and political determinants. Oxford Development Studies, 40(4), 492-516. https://doi.org/10.1080/13600818.2012.728580

Hellendroff, B. (2011). China and DRC: Africa's next top models? Note d'Analyse 13. Retrieved from: https://docplayer.net/7952542-China-and-drc-africa-s-next-topmodels.html

Hill, C. (2015). The role of the tiger and the elephant in the ascent of Africa: Partners or neo- 
colonialists? Honors Thesis. Retrieved from University of Tennessee: https://scholar.utc.edu/honors-theses/20

Huaxia (2018, October 26). 70 pct of Ethiopia's sesame export go to China. Retrieved from Xinhua: http://www.xinhuanet.com/english/2018-10/26/c_137560997.htm

Jayaram, K., Kassiri, O., \& Sun, I. (2017). The closest look yet at Chinese economic engagement in Africa. Mickensey Report: Mickensey and Company.

Kaplinsky, R., \& Morris, M. (2012). Chinese OFDI in Sub-Saharan Africa. In Chinese international investments (pp. 300-325). London: Palgrave Macmillan.

Khatoon, A., Rahim, N., \& Ali, B. (2018). A historical perspective of China's peaceful politics and its rise as world economic power. Liberal Arts and Social Sciences International Journal, 2(1), 65-74. https://doi.org/10.47264/idea.lassij/2.1.8

Laingyu. (2018, October 24). Interview: Ethiopia eyes boost in sesameexport to China amid growing demand. Retrieved from Xinhua: http://www.xinhuanet.com/english/2018$10 / 24 / \mathrm{c} \quad 137553206 . \mathrm{htm}$

Muzaffar, M., Yaseen, Z. \& Rahim, N. (2017). Changing dynamics of global politics: Transition from unipolar to multipolar world. Liberal Arts and Social Sciences International Journal (LASSIJ), $\quad 1(1), \quad 49-61$. https://doi.org/10.47264/idea.lassij/1.1.6

Naidu, S. (2008, September 3). Africa's New Development Partners: China and India: Challenging the Status Quo? Retrieved from: https://www.pambazuka.org/globalsouth/china-and-india-africa-challenging-status-quo

Novati, G. P. C. \& Montanini, M. (2016). Energy and the regional players: The odd rivalry between the EU and China in Africa. In: Godzimirski, J. M. (ed.) EU Leadership in Energy and Environmental Governance. International Political Economy Series. London: Palgrave Macmillan, 135-155.

Pelssis, A. (2014). The forum on China-Africa cooperation, ideas and aid: National interest(s) or strategic partnership? Insight of Africa, 6(2), 113-130. https://doi.org/10.1177/0975087814535440

Rehman, A. U., Hakim, A., Khan, K., \& Khan, I. U. (2018). Role of CPEC in Development of Trade, Transport and Economy of Pakistan. Romanian Journal of Transport Infrastructure, 7(1), 77-92. https:doi.org/10.2478/rjti-2018-0005

Shelton, G. (2008). South Africa and China: A strategic Partnership?' In: Alden, L. \& Oliveira, S. D. (eds). China returns to Africa: A superpower and continent embrace. London: Hurst.

Sow, M. (2018). Figures of the week: Chinese investment in Africa. Brookings assessment and analysis. Avaialbel at: https://www.brookings.edu/blog/africa-infocus/2018/09/06/figures-of-the-week-chinese-investment-in-africa

Sun, Y. (2014, April). Africa in China's foreign policy. Thornton China Centre and Africa Growth Initiative. Brookings: https://www.wlv.ac.uk/media/departments/faculty-ofsocial-sciences/documents/Africa_in_China_Brookings_report.pdf

Sun, Y. (2018, September 5). China's 2018 financial commitments to Africa: Adjustment and recalibration. Brookings; Africa in Focus. https://www.brookings.edu/blog/africa-infocus/2018/09/05/chinas-2018-financial-commitments-to-africa-adjustment-andrecalibration/

Sun, Y. (2019, February 4). China's changing approach to Africa. Brookings, Africa in Focus. https://www.brookings.edu/blog/africa-in-focus/2019/02/04/chinas-changingapproach-to-africa/

Tanimoune, N. A. \& Renard, M. F. (2011). FDI convergence and spatial dependence between 
Chinese provinces. Retrieved from HAL: https://halshs.archives-ouvertes.fr/halshs00570498/document

The State Council China. (2013). China-Africa economic and trade cooperation. The State Council; The People's Republic of Chian. http://english.www.gov.cn/archive/white_paper/2014/08/23/content_281474982986 536.htm

Thompson, R. (2012). Assessing the Chinese influence in Ghana, Angola, and Zimbabwe: The impact of politics, partners, and petro. Stanford University: Centre for International Security and Cooperation.

Witney, S. \& Wiegert, J. (2018, April 16). Contemplating in Africa:China the European Union and the United States. Brookings; Africa in Focus. https://www.brookings.edu/blog/africa-in-focus/2018/04/16/competing-in-africachina-the-european-union-and-the-united-states/

Zafar, A. (2017). The growing relationship between China and Sub-Saharan Africa: Macroeconomic, trade, investment, and aid links. The World Bank Research Observer, 22(1), 103-130. https://doi.org/10.1093/wbro/lkm001 